\title{
Parenting Education: Building Characters and Holding in Millennial Mental Problems
}

\author{
Agung Wiradimadja \\ Universitas Negeri Malang \\ Malang, Indonesia \\ agung.wiradimadja.fis@um.ac.id
}

\begin{abstract}
This research was conducted to see parents effort in improving their parenting skills, especially in building children's character education. Parental education is very important and crucial for children. During 2007 to 2009 there were cases of juvenile delinquency which involves teenagers aged $\leqslant 18$ years and cases of mental decline. This cases shows that there is a moral decline or character of millennial generation. Millennials tend to have weak mentality compared to the previous generations. This also indicates that the role of the family in shaping character to the millennials are not going well. This research was conducted using qualitative methods. The data was collected by conducting in-depth interviews with 21 parents who had children aged between 2-18 years as respondents. The collected data is reduced, interpreted and analyzed. The results of the study are presented in a narrative descriptive manner. The purpose of this research is to find out whether parents prepare themselves with the science of parenting.
\end{abstract}

Keywords: parenting education, millennial mental problems, children's mental problems, character education

\section{INTRODUCTION}

Marriage is one step to obtain legitimate offspring. For some people, getting offspring opens up new experiences and can change their daily routines. Some Indonesians consider marriage and having children as ways to improve their status in society. So that everyone in Indonesia, in general, has the desire to get married and have children. New parents have additional responsibilities to take care of their children. Some people assume that parenting has a little effect on children's development [1]. However, various evidence states that parenting plays effective role in reducing mental problems such as adolescent behavior and emotional [2]. Parenting is an ability that must be possessed by parents in educating and fostering children. Not only for the physical growth and development of children, but also for building psychological health such as the formation of character and mental.
Overall, $42 \%$ of the world's human population are teenagers under 24 years. $90 \%$ of them live in low-income and middle-income countries [3]. Children and adolescents in low and middle income countries, or developing countries like Indonesia, are more prone to have poor mental health. Conditions of lack of psychological care for children, poverty and violence make them even more vulnerable. Family environment should be the most powerful environment and can take preventive actions to maintain the welfare of then children [4]. Mokdad said the mental health problems are one of the things that make youth productivity declines [5]. The phenomenon revealed by Mokdad also occurred in Indonesia. Previously, researchers assumed that many parents were apparently not ready to carry out their role as parents. Researchers often see parents unable to fulfill parenting services that are good enough for their children. Especially psychological education services. This has an impact on mental health development and character of millennial adolescents that are not growing well. Many cases of millennials who commit acts of misbehavior that lead to social deviations violate regulations and even engage in criminality. Those acts include consuming alcohol, not being disciplined in driving, consuming drugs, theft, fraud, rape, against parents, fights to murder and so forth.

In recent years, there has been a decline in children's mental health and character. Based on criminality data from the National Police Headquarters, BPS recorded an increase in criminality committed by millennial youth from 2007 to 2009. In 2007, there were 3,145 criminal cases committed by adolescents aged $\leqslant 18$ years. In the following year, there is an increase in criminal cases committed by adolescents which is 3,280 in 2008 and 4,123 in 2009. The 
character building in parenting. The research was conducted in Malang Raya, which covers Malang city, Malang Regency and Batu City.

\section{METHOD}

The design of this study is descriptive qualitative methods. Where the data obtained is reduced, interpreted, analyzed, then the research results are presented in a narrative description.

The research respondents were determined by a purposive sample technique. The selected participants in the study are families who were married between 1990 and 2017 and have children aged between 2-18 years. Restrictions of respondents are based on the purpose of the study to examine parenting conducted by parents whose children are the millennial generation. The number of respondents who were interviewed was 21 families. These families are scattered in Malang Raya. The list of respondents was obtained from the marriage data of the Office of Religious Affairs (KUA) and the smallest official goverment organization namely RT and RW. KUA as a civil marriage registration, also has the task to carry out premarital seminars for prospective brides. This seminar became the foundation in building households and parenting. The smallest official goverment organization RT and RW usually has a close relationship with the people in their working area, so that they can provide information about the respondents needed in this study.

The data collection was done by semi-structured interviews in order to get in-depth information from research respondents. Interview guidelines are designed specifically to get information on what efforts have been made by parents to add insight into parenting [11]. Data from interviews that were collected by researchers were reduced, then analyzed through discussion with the results of other studies.

\section{RESUlTS AND DISCUSSION}

The parents stated that they had received parenting education to build their children's character. They get parenting education before and after they get married. The parenting education they got was not specific from the parenting training course as a parent, but from various efforts have been made by parents to get parenting education, and (3) whether parents try to instill children's 


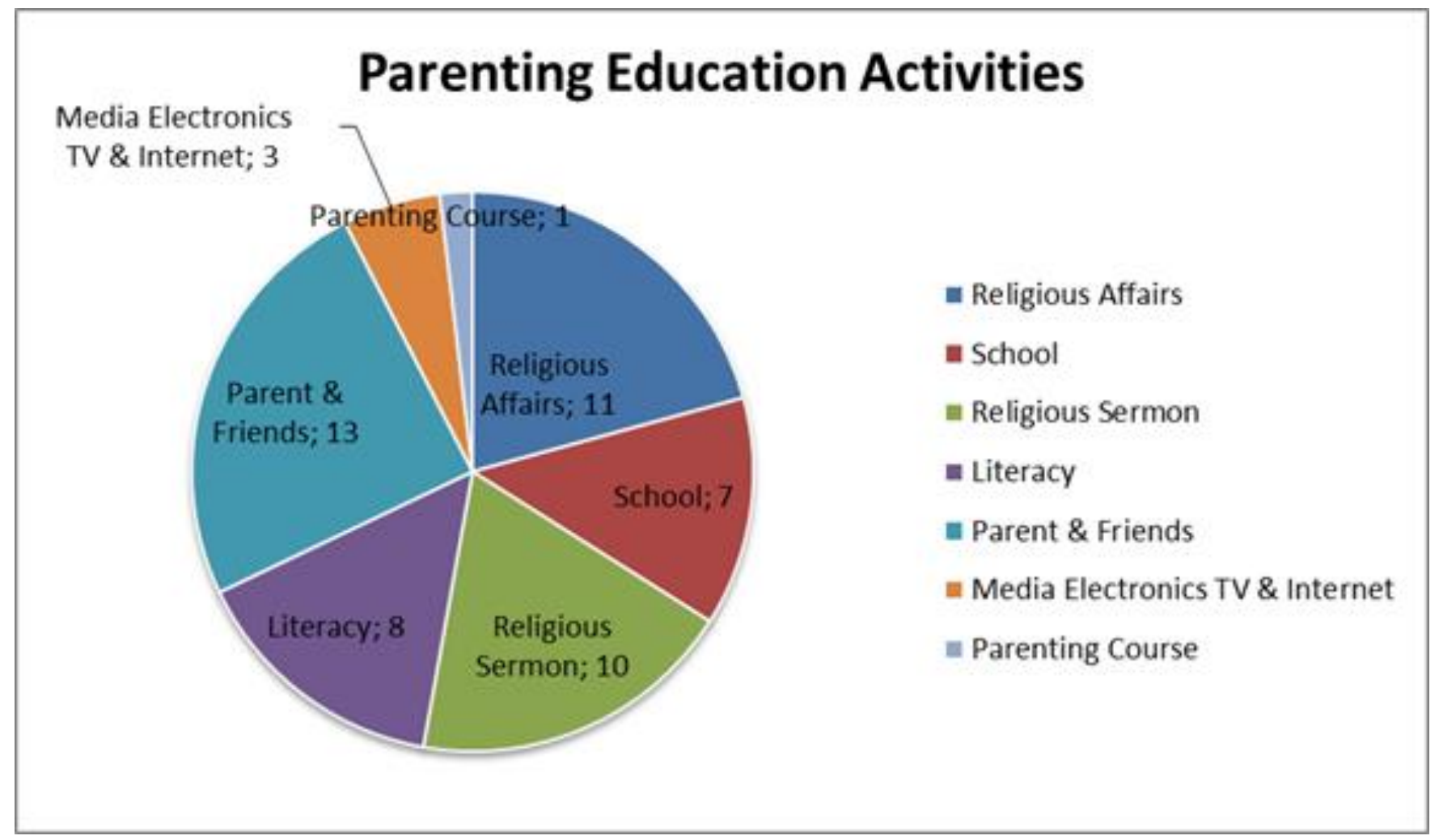

Fig 1. Parenting Educational Activities

The parents said they participated in perenting activities through several activities such as premarital seminars, school education, religious propaganda, various literacy, consultation to parents as well as colleagues, electronic media and also parenting training. Parenting education activities organized by the state are through premarital seminars from KUA institutions. Eleven of the respondents stated that they participated in the premarital seminar. This activity is held for the bride and groom who will hold a wedding. This activity is carried out around three months before the wedding. Some of the material provided is parenting education which is useful for mental health and character building of children. But in some areas in Indonesia, this premarital seminar has not been made a compulsory course for prospective brides. So that not all brides participate in these activities, especially for workers. Some respondents stated that they were too busy working, so they could not attend the premarital seminar.
Seven respondents said they got parenting material when they learn at school, during Religion lesson. They stated that the teacher did not convey parenting material specifically as the main material, but in some chapters of the subject. Ten respondents said they attended parenting education from religious lectures in places of worship such as mosques and churches. They stated that they often join religious lectures in their usual places of worship. On several occasions, religious leaders raised the theme of parenting in their religious discourse. A total of eight respondents studied parenting through literacy studies such as reading books or magazines. They stated that they tried to enrich their knowledge through studying books or magazines that contained writings about parenting. The books they have are deliberately bought from bookstores and there are also some who say they borrowed it from colleagues, while the magazines they get from when they attend pre-marital seminars at KUA. As many as three 
Field research shows that parents understand the

people said that they had participated in electronic media programs such as TV shows and videos on the internet. Only one person participated in parenting training activities. He said that he attended a psychological service parenting training organized by the village government under the name of the "Love Parenting Education School" activity. The most common activity undertaken by respondents was to consult and seek advice from married parents and colleagues. Based on the explanation of the respondents, they felt it was more practical to consult with parents and colleagues. They can also trust more quickly when studying with people who are already close to them. Only one person who participated in parenting training activities. He said that he attended a parenting training organized by the village government under the name of the "Pendidikan Parenting Sekolah Cinta" activity. The most common activity undertaken by respondents was to consult and seek advice from married parents and colleagues. Based on the explanation of the respondents, they felt that it was more practical to consult with parents and colleagues. They can also trust more quickly when studying with people who are already close to them.

The respondents also said that they also instilled character education to their children in parenting. However, not all respondents know the 18 values of character education determined by the Indonesian education office. Based on the explanation of the respondents, they only apply some character values which are general and in accordance with values and cultural norms, such as honesty, religious, discipline, tolerance and others. This is applied in children's daily activities. The few examples given by respondents includes (1) always reminding their children to make their beds every morning, (2) reminding them to not forget to pray, (2) telling them not to be honest, and respect others. The parents stated that they felt the implementation of character education for their children was not so optimal. This is because many of them are worker s who work more than 8 hours a day. So that the socialization or parenting process is not so intense in the family. The parents said that they rarely have family activities together even on weekends. Then, in their teenage years, their children prefer to play with friends outside the home. This makes it difficult for parents to control their children's social interaction. importance of building children's mental health and character. Because mental health and character education can provide information and social skills needed by children and young people of the nation to become citizens who have noble ethics and virtues [12]. Long in his research stated that mainstream education practices effectively reduce children's mental and character problems [11]. Every parent expects their children to have good character. This is a form of love and affection of parents towards their children. They prepare themselves with parenting training both before and after they get married. Family is a very important aspect in the process of children's character building. Because they realize that the task of parents is to provide education to their children [13].

Parents attend parenting education training to increase their insight in instilling children's character education through various activities. The activities include premarital seminars, parenting education while at school, religious studies, reading books or papers, consulting parents and colleagues who are married, watching TV programs related to parenting, reading parenting materials through the internet, and also taking parenting courses. Parenting education through a variety of activities and institutions similar to those conducted by people in the City of Kansas. Based on the explanation Barrett, the institutions that can be used as a study of family character development in the City of Kansas are schools, places of worship (religion), communities, and also the country [13]. This activity is closely interrelated in the education process, so that this becomes an effort of cooperation between individuals and the community [13]. It's just the difference in Indonesia, premarital seminars organized by KUA institutions (as state institutions) in collaboration with various religious community organizations in their implementation. The government does not establish special institutions managed by the state in providing premarital training. Unfortunately the state does not care much about the importance of parenting for the family's social-psychological health. The government has not made regulations that requires all citizens to attend parenting education. So that each family member can carry out his role to achieve harmonious family goals. 
Parents state that they are trying to instill education in their children through parenting. They teach character values through small things to instill honesty, religious, discipline, tolerance and others. The implementation of character values through parenting education has succeeded in reducing mental and character problems of children in America [10]. The expectation of parents, this also helps their children to grow into citizens who are obedient to parents as well as cultural and state norms. But because of the rush of work, parents acknowledge that the implementation of character education in families is not so optimal. High working hours activities of parents and activities of children who prefer to play with friends make the character building less intense. Parents also say that it is difficult to control children's social interaction when they are not with their children

\section{CONCLUSION}

The parents prepare themselves by adding insight into parenting education to shape the mental and character of the child. Parenting education they did was obtained from various activities such The activities include premarital seminars, parenting education while at school, religious studies, reading books or papers, consulting parents and colleagues who are married, watching TV programs related to parenting, reading parenting materials through the internet, and also taking parenting courses. Parents try to build the character of their children in the parenting process, but they feel that the implementation is not optimal. This is because parents' activities at work and children's preference to play with their friends makes them rarely meet.

\section{REFERENCES}

[1] W. A. Collins, E. E. Maccoby, L. Steinberg, E. M. Hetherington, and M. H. Bornstein, "Contemporary research on parenting: The case for nature and nurture.," American Psychologist, vol. 55, no. 2, pp. 218-232, 2000.

[2] M. R. Sanders, "Family observation schedule. Parenting and Family Support Centre: Brisbane.," 2000.

[3] C. Kieling et al., "Child and adolescent mental health worldwide: evidence for action," The Lancet, vol. 378, no. 9801, pp. 1515-1525, Oct. 2011.
[4] G. A. Pedersen et al., "Correction to: A Systematic Review of the Evidence for Family and Parenting Interventions in Low- and Middle-Income Countries: Child and Youth Mental Health Outcomes | SpringerLink." [Online]. Available: https://link.springer.com/article/10.1007/s10826-01901498-2. [Accessed: 25-Jul-2019].

[5] A. H. Mokdad et al., "Global burden of diseases, injuries, and risk factors for young people's health during 1990-2013: a systematic analysis for the Global Burden of Disease Study 2013," The Lancet, vol. 387, no. 10036, pp. 2383-2401, Jun. 2016.

[6] BPS, Profil Kriminalitas Remaja: Studi di Lembaga Pemasyarakatan Anak di Palembang, Tanggerang, Kutoarjo, dan Blitar. Jakarta: Badan Pusat Statistik, 2010.

[7] M. Reksodiputro, "Sistem Peradilan Pidana Indonesia," Pidato, 1993.

[8] R. Kasali, Strawberry generation [sumber elektronis]: anak-anak kita berhak keluar dari perangkap yang bisa membuat mereka rapuh. Bandung: Mizan Pustaka, 2018.

[9] L. Winter, A. Morawska, and M. Sanders, "The Knowledge of Effective Parenting Scale (KEPS): A Tool for Public Health Approaches to Universal Parenting Programs," The Journal of Primary Prevention, vol. 33, no. 2-3, pp. 85-97, Jun. 2012.

[10] N. Long, "Special Section: Learning from Experience: Shifting from Clinical Parent Training to Broader Parent Education," Clinical Child Psychology and Psychiatry, vol. 12, no. 3, pp. 385392, Jul. 2007.

[11] M. R. Sanders, C. K. Dittman, L. J. Keown, S. Farruggia, and D. Rose, "What are the Parenting Experiences of Fathers? The Use of Household Survey Data to Inform Decisions About the Delivery of Evidence-Based Parenting Interventions to Fathers," Child Psychiatry \& Human Development, vol. 41, no. 5, pp. 562-581, Oct. 2010.

[12] E. F. Schaeffer, "It's Time for Schools To Implement Character Education," NASSP Bulletin, vol. 83, no. 609, pp. 1-8, Oct. 1999.

[13] S. M. Barrett, "Character Building," Journal of Education, vol. 109, no. 21, pp. 582-584, May 1929. 